\title{
hook, line, and sync her: \\ fishing in/out questions of competency, regulation, and authority \\ Janice Hladki
}

\section{L'hameçon dissimulé derrière les questions de compétence, de réglementation et $\mathrm{d}$ 'autorité}

Ce texte écrit arrive à transformer un essai académique en une performance multimédia. Hladki inscrit son corps sur la scène du pouvoir académique en posant les questions suivantes : où et comment les présentations prennent-elles place? quia la compétence de présenter et quel corps fait autorité? Ce texte combine différents médiums représentationnels comme des citations, des instantanés, des didascalies et des dialogues. La dynamique textuelle utilise des photographies d'une expédition que la famille de l'auteure a entrepris lorsqu' elle était enfant et ceci, pour refléter les enjeux personnels et politiques présents dans les désirs de compétence et d'autorité. Utilisant les disjonctions introduites par les différents médiums représentationnels, "L'hameçon dissimuléderrière les questions de compétence, de réglementation et d'autorité» veut, à la fois marquer les contradictions et les retouches que Hladki apporte à son autobiographie, et inviter le lecteu ret la lectrice à prendre position dans le complexe thêâtre de l'autoritaire production signifiante. Comment se sent-on lorsqu'on nous interpelle? Lorsqu'on nous demande de participer à la performance? Sommes-nous accrochés? Ou confondus?

\section{Program Notes}

This written text is a script for a mixed media(ted)/mixed meaning presentation/performance. "hook, line, and sync her" accommodates, appropriates, negotiates, and intervenes in performance and academic presentation forms. It attempts to weave a number of concerns and to struggle with them in a non-linear form that also inscribes my body politically - in the writing of the text.

This performance piece explores my investments, as a doctoral student, in learning what might constitute a "legitimate" academic 
presentation. With this focus, the work also questions notions of how I understand performance art production: where and how it takes place and for what purposes. "hook, line, and sync her" performs the body in a complex and ambiguous relationship to these investments and concerns. I simultaneously accept and protest the demonstration of the competencies that I think I should display. ${ }^{1}$

I use a particular autobiographical moment, ${ }^{2}$ reflected in my family photographs of a fishing "expedition," ${ }^{3}$ to suggest the combination of pleasure/pain and personal/political. This self-representation inscribes my floundering, as a child and as an adult, as I continue my (in)vested interest in competency. Conjunctions of gender, sexuality, race, and class are implicated in these family "snaps," and meanings (and metaphors) are explored through a non-reductive interplay with other elements in the presentation.

I understand "hook, line, and sync her" as an instalment in an ongoing political project of examining complex contradictions, accommodations, and contestations in my history as a white, working-class woman, as a privileged educated woman, as a cultural worker who appropriates popular culture forms in her work.

In the juxtaposition of various elements in the presentation - spoken text, audio text, music, physical gesture, visual and written transparencies, on-site video, a video of a film-Iattempt to subvert a narrative organization. An entanglement of forms and meanings is deliberate. My intent is both a self-provocation, through my embodied rendering of the presentation, and a provocation of the audience's relationship to, and involvement in, the production of an academic presentation. ${ }^{4}$

\section{Technical Presenters}

An operator of the slide projector and someone on camera videotaping the presentation are in the middle of the audience's seating area. Consequently, they are visible to the presenter, and the presented to, throughout. Except for a few occasions, the operator of the slide projector changes the transparencies only when cued by the presenter. The cameraperson, however, improvises a continual taping of the presentation, and this begins while the audience enters and sits and while the presenter organizes her material. The videotaping underlines the act of spectatorship and the representational status of the presenter. 


\section{Physical Incription}

The bodily gestures of the presenter are marked by their intentionality: They are (over)emphasized through movement that is slow, purposeful, and direct. This includes the gestures of the work involved in presenting, such as using a pointer and dealing with the equipment, as well as those gestures that are more abstract, such as cupping one hand over the mouth. The presenter walks in a studied and careful manner. She is acutely aware of direction, level, focus. Although the technical presenters do not "speak" - verbally, that is - they too move with focus and intention.

\section{THE SCRIPT...}

(When the presenter enters the room she carries audio cassettes, a video tape, a pointer, and a file folder with transcripts of the audio material and other writings. She sits at the desk and organizes the materials for the presentation.)

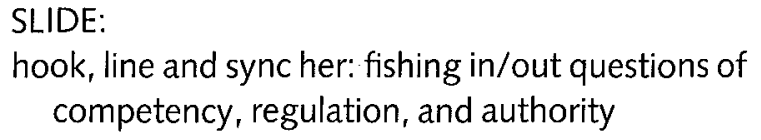

(The presenter stands and walks to the door of the room.)

\section{SPOKEN TEXT:}

(confidentially) Studies demonstrate that audiences get

nervous (pause) if the presenter moves around too much.

(Walking to the screen and pointing to the slide)

(with a smile) Studies demonstrate that a catchy title - with a colon, in two parts, and in lowercase - can capture the audience's attention.

SLIDE:

The personal politicized and the political personalized is the in-between ground where the questioning work materializes itself and resists its status as mere object of consumption.

- Trinh T. Minh-Ha 


\section{SPOKEN TEXT:}

(The presenter walks to the desk and stands beside it.)

(breathy) Studies demonstrate that gesticulation, used appropriately, can emphasize your points.

(The presenter enacts gestures, slowly and with overemphasis, that articulate the meanings of the following line. The movements are odd renderings of common functional gestures.)

Studies demonstrate that some, but not too many, audio visual elements can enhance your lecture.

(Standing by the desk and looking at the screen.)

SLIDE: (Photograph of Janice with fish)

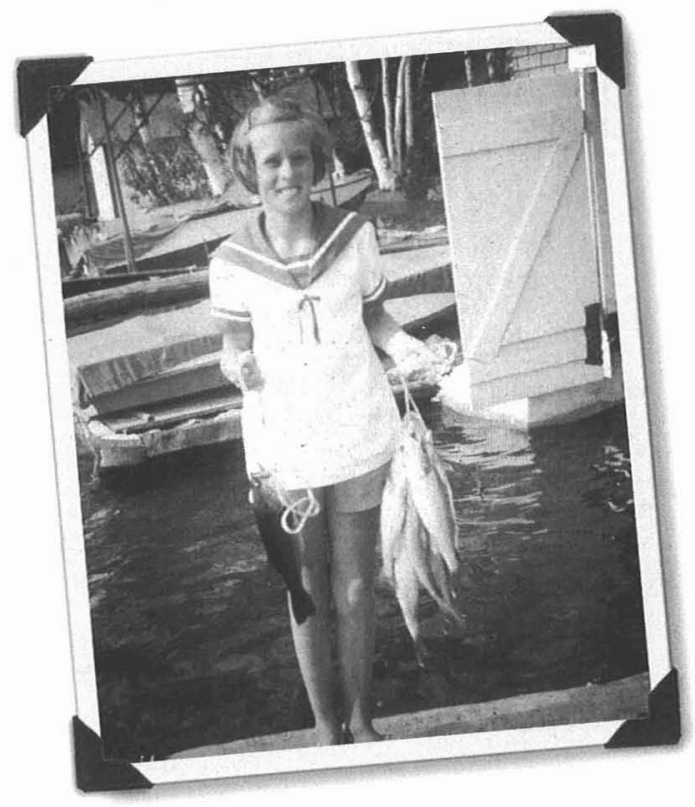

\section{SPOKEN TEXT:}

(slowly, to one audience member) Studies demonstrate that autobiographical material can detract from a presentation and can be read as confessional. 
(The presenter walks around the desk, sits down, and looks at the screen where the slides are projected.)

SLIDE:

Some of the fish have scales that must be removed before eating Some of the fish are rising with their teeth in black rows.

My hands grip into the softness of their gills.

My fingers are wet \& the gills lift open, involuntary.

It is what the pain allows.

It is the start of food.

- Erin Mouré

\section{SPOKEN TEXT:}

(quickly and nervously) Studies demonstrate that judicious citations can support your position.

SLIDE:

We need to analyze the mechanisms of power inherent in the discourse of fishing.

- Michel Foucault

The interests which the discourse of fishing serves may be very far from those which it appears, at first sight, to represent.

- Chris Weedon

Fishing is a closed system that already contains and recaptures all resistance.

- The Frankfurt School

Hladki's use of the fishing fotos foregrounds issues of fragmentation and contemporary filosophical debates.

- The Birmingham School

\section{SPOKEN TEXT:}

Studies demonstrate that audience members do not like to be asked to volunteer.

(The presenter holds a long pause while looking at the audience.)

May I have a volunteer from the audience? 
(A volunteer, or the presenter as volunteer, reads)

I'm delighted to have the opportunity -

It's a great pleasure to have -

I want to thank -

I am honoured to present -

Our speaker:

publishes widely

teaches broadly

edits voluminously

researches extensively

Our speaker is:

a large presence on the intellectual horizon an academic persona

part of a star-studded intellectual stable

SLIDES: (Projected during volunteer's reading)

1) Audience:

Please synch $r$ o nize your watches

2) The process of knowledge is motivated by desire: what moves the show along is the relation of self to other, and the desire to be desired, the desire for recognition and a mirroring of the self by the other.

- Ann Game

\section{SPOKEN TEXT:}

(to volunteer after reading) Thank you.

\section{SLIDE:}

Some of our desires are known only on the floor of oceans, the nets dragged thru, a light beyond colour we can't imagine, where we live now, people of the surface, whose foetuses still bear gills for a few days \& lose them, our kinship, the water inside women, water where we form \& grow. 
The halibut frozen whole, a sheet of memory, held up thawed, cut into slices

across the body, the central location of the spine, our shared spine, small bone hands of its vertebrae, evolved away from us.

- Erin Mouré

\section{SPOKEN TEXT:}

(The piece is from Ernest Hemingway's story, "Big Two-Hearted River: Part II.")

Looping in the line with his left hand, Nick swung the rod to make the line taut and tried to lead the trout toward the net, but he was gone, out of sight, the line pumping. Nick fought him against the current, letting him thump in the water against the spring of the rod. He shifted the rod to his left hand, worked the trout upstream, holding his weight, fighting on the rod, and then let him down into the net. He lifted him clear of the water, a heavy half circle in the net, the net dripping, unhooked him and slid him into the sack.

SLIDES: (During reading)

1) (Photograph of fish on the dock)

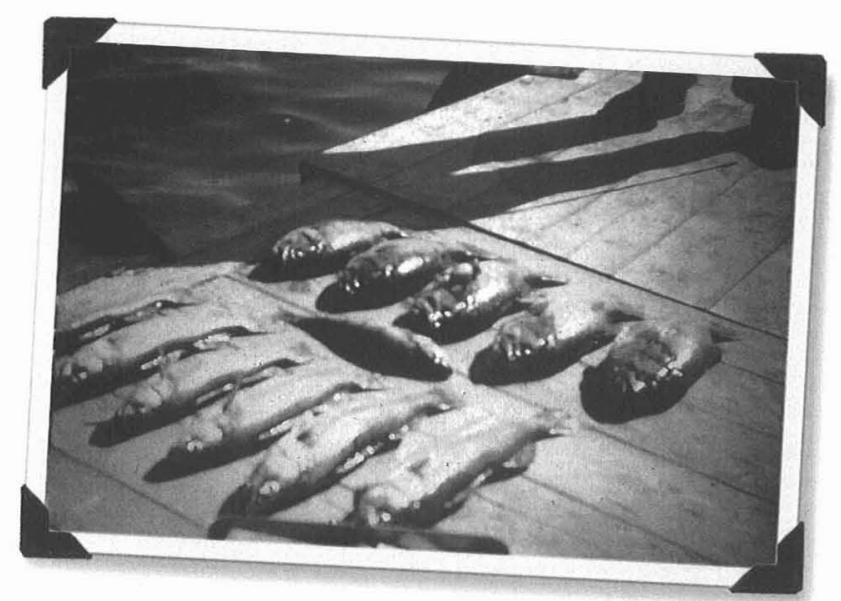




\section{2) (Photograph of Lorraine and I)}

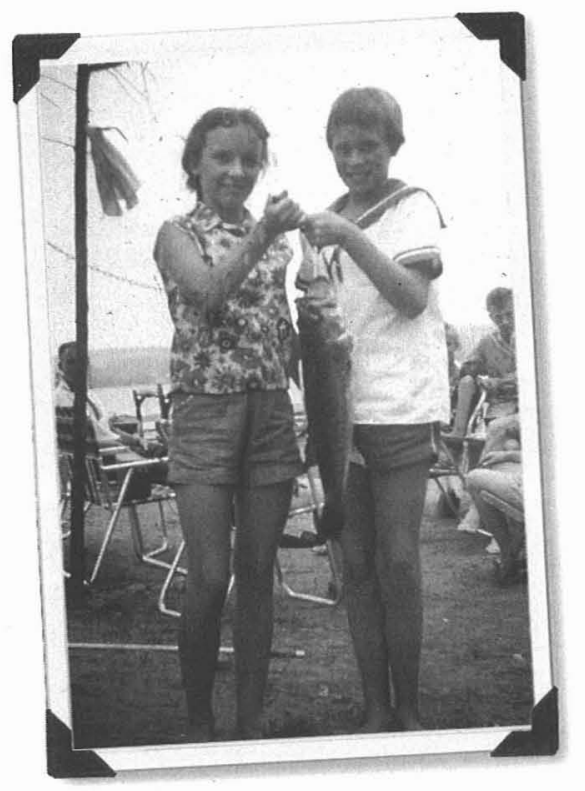

(The presenter repeats the earlier gestural sequence while sitting, then stands, sits, stands again, and repeats the movements once more.)

\section{VIDEO:}

(The presenter puts the video in the VCR and watches it. The clip is from the film, The Island; the scene is a father $(F)$ and son (S) fishing. The following video and slide texts play at the same time.)

\section{SLIDES:}

1) How is power exercised? - Michel Foucault

2) Audience:

Are you knowable?

Do you read me as authority?

Do you interrogate me?

Do I interrogate you? 
S: I haven't even had a bite yet.

F: Give it time.... There's blue water out there. That's where the big ones are.... Hey! You got one! Oh, that's great, Jeff! Hang on! Hang on! Don't give it any slack. Slowly! Pull it in slowly! Pull. Don't leave any slack. Wait! Wait! Don't leave slack. Don't try and take it from him, just give it to him. Yeah, snap it! Give him slack. Okay, pull. Slowly! Slowly, slowly. Hey! Hey! Bring him to the side. I'm going to hit him with this. Bring him to the side. I'll pull him up. Don't bring him up! Don't bring him up! Leave him down! Leave him down! Bring him down.

S: Hey, what are you gonna do?

F: There he is.

S: What's the matter?

F: He's got to be unconscious before you bring him into the boat. You get one of these alive, they really give you trouble.

S: What is it?

F: What did you want?

S: A barracuda.

F: That's what you got.

S: Really?

F: A barracuda. About 9 or 10 pounds. Two and a half feet.

S: Outrageous!

F: Look at those teeth! Hmm! [Laughs] Pity we lost the camera on the plane. We could have taken a picture for your mother. Tell her it was in a pond at Disneyworld...Right. Let's get back.

S: Why?

F: Well, it's getting a bit late.

S: You said we could spend a whole day fishing.

F: Well, we have.

S: Let's catch another fish.

F: We got one.

S: This one may spoil by the time we get back.

F: It won't spoil. You can stuff it...Okay! Okay, okay. Let's give it another try. 
hook, line, and sync her $\cdot 117$

3) (Photograph of Dad squinting, with fish)

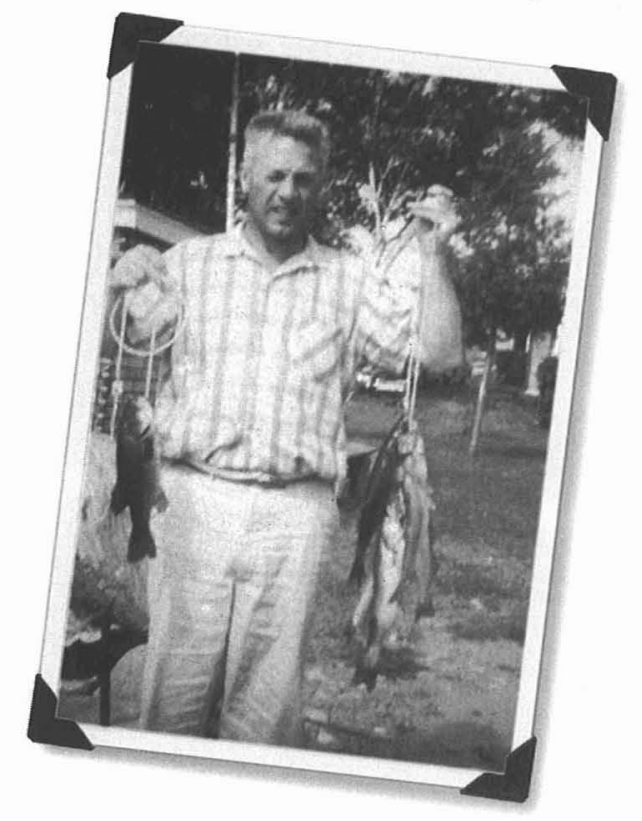

4) (Photograph of our family and fish)

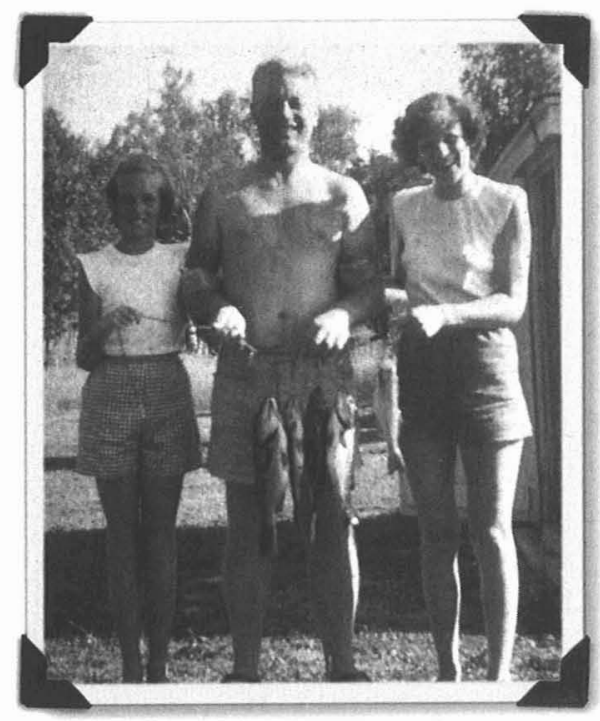




\section{5) (At end of video)}

The pain from which we speak, we speak to pull the hook of our words thru the other's lip, nearest the bone, tearing it, saving the hook

- Erin Mouré

(The presenter turns off the video.)

6) Please do not consume this text.

\section{AUDIO:}

(The presenter lip-syncs to this audio text which is a quotation from Valerie Walkerdine's Schoolgirl Fictions. She lip-syncs out of time, but continues to read as if the physical and aural texts were in alignment.) There is, in this account, no lone individual, no single point of causality, but subjects created in multiple causality, shifting, at relay points of dynamic intersection. We can take apart the facts of complementarity, of male and female, rational and irrational, active and passive, mental and manual, which form the sites and possibility of our subjugation and of our resistance. We might then adopt a double strategy: one which recognizes and examines the effects of normative models, whilst producing the possibility of other accounts and other sites of identification. Current accounts of the family and schooling which deny power and desire in a humanistic conception of nurturance serve to help keep us locked inside a powerful fiction of autonomy and possibility, which is not to be countered by a total pessimism but rather by a working with and through an exploration of both our own formation in all its historical specificity and the formation of other possibilities of practice, as well as locations from which to struggle within existing ones. Thus, a working within those apparatuses of our present means not only our attempts at deconstruction but the possibilities for explorations which do not seek a knowledge which claims itself as true for all people, places, times.

\section{SLIDES: (During lipsynching)}

1) Some of our desires are known only here, are only now being let loose \& admitted, have only this moment stopped being ashamed, 
ashamed of the shape our bodies took \& stayed on land when the fish said No \& went back into the water, mistake, mistake, fuck the lungs, some of our desires are known only on the ocean floor, in the head

of the flatfish, halibut lying on its left side, the eye that migrated across its skull staring upward with the other.

At rest with it, patient.

Some of us have lungs that suffocate in the air. The human body, two eyes fixed in the skull, a third eye that presses on the forehead $\&$ gets nowhere, presses \& lives, its silence the silence under oceans, in the deep water of the body, its blind side facing the brain - Erin Mouré

2) (Photograph of Janice with fish)

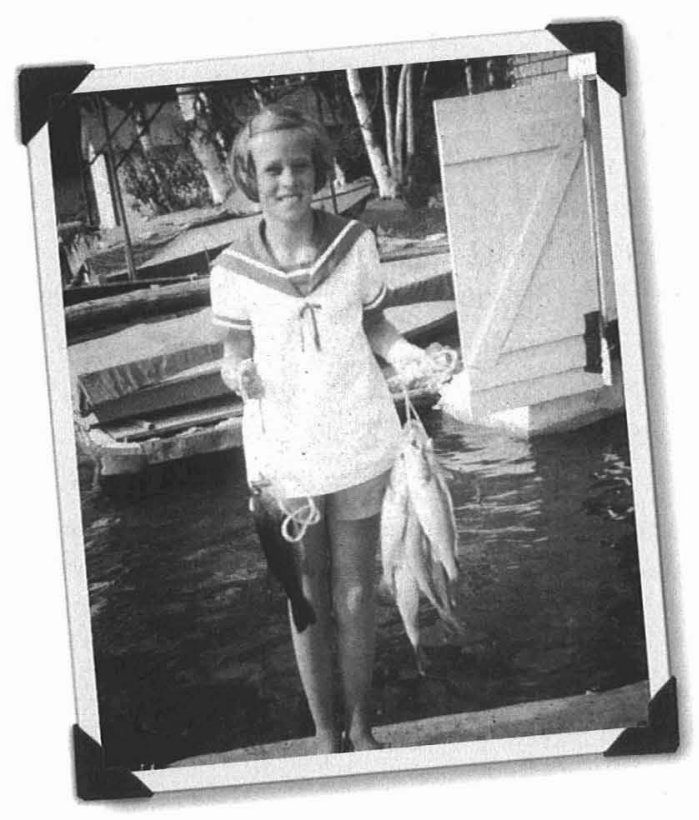


3) (Photograph of single fish on net)

(Hold on this slide)

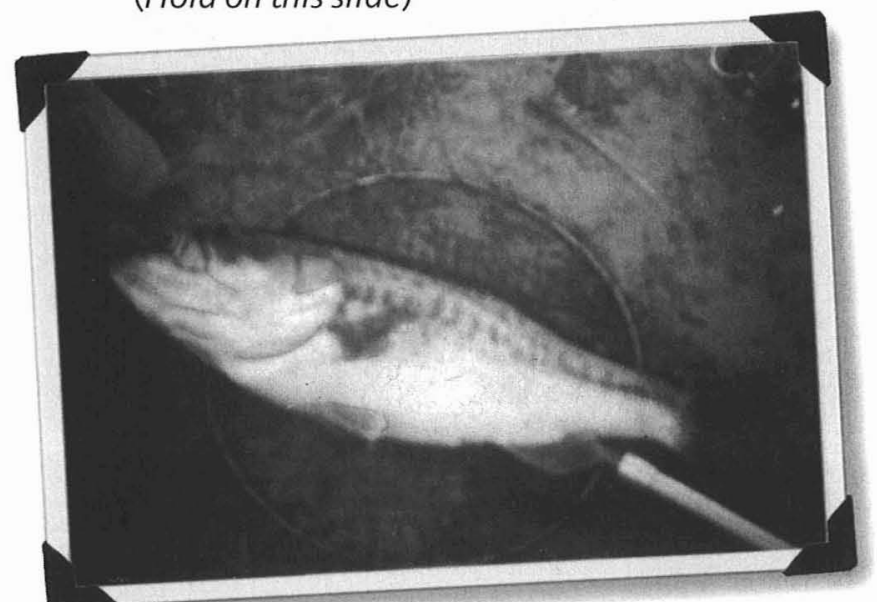

SPOKEN TEXT:

invested in the ingestion

the digestion.

saturated desires.

reproduced and reproducing.

fishing as fissure.

like the small-mouth bass, she has representational status.

landed

netted

her gills open

and close.

(The presenter begins to organize her materials. She holds the cassettes, the file folder, the video, and the pointer and stands. She walks into the audience to the technician presenters, thanks them, and tells them the presentation is over. The slide projector is turned off, but the video of the (post)presentation continues.) 


\section{Notes}

1. I first performed a version of this work as a requirement for a graduate class addressing feminist poststructuralist theories at OISE in 1993. The performance piece was initiated within the specific context of this doctoral course work and produced for marks. Thus, in other layers of investment, I was, at that moment of academic performativity, attempting to constitute myself as competent graduate student in relationship to professor.

2. I have examined this particular historical moment in my life, at age 11 , with reference to issues of class, immigration, gender, and sexuality in other work. See Bower, M., \& Hladki, J.(Writers \& Directors). (1991). Decomposure [Video]. Canada. 14 min.; Carroll, S., Davidson, A., \& Hladki, J. (1992). Oddgirls out. Unpublished manuscript, Ontario Institute for Studies in Education, University of Toronto.

3. I use a number of "fish" writings in this text. In reflecting on Mouré's fish poems, Margaret Christakos suggests that for Mouré "the fish's wriggling muscle to survive is a metaphorical rigour for breathing, for adapting in extreme dislocation, in conditions of power upturned, of choice stripped away" (1992 52).

4. In developing the concerns of this presentation, I am indebted to the work of a number of people. For examining memory through a political kaleidoscope: Sue Friedrich, Frigga Haug, Audre Lorde, Marion McMahon, Cherríe Moraga, Ngozi Onwurah, Minnie Bruce Pratt, Kathleen Rockhill, Jo Spence, Carolyn Steedman, Valerie Walkerdine. For written and/or conversational reflections on the production of knowledge and power relations in educational sites: Suzanne Carroll, Linda Cullum, Kari Dehli, Elizabeth Ellsworth, Marnina Gonick, Jennifer Gore, Victoria Littman, Kate McKenna, Sandra Moffat, Mimi Orner, Kathleen Rockhill, Roger Simon, Valerie Walkerdine, and Patricia J. Williams.

\section{Works Cited}

Bower, M., \& Hladki, J. (Writers and Directors). Decomposure [Video]. Canada. 14 min.(1991).

Carroll, S., Davidson, A., \& Hladki, J. Odd-girls out. Unpublished manuscript, Ontario Institute for Studies in Education, University of Toronto. (1992).

Christakos, M. Three versus. Open Letter, 8(4), 40-55. (1992).

Foucault, M. The subject and power. Critical Inquiry, 8, 777-795. (1982). 
Game, A.Undoing the social: Towards a deconstructive sociology. Toronto: University of Toronto Press. (1991).

Hemingway, E. Big two-hearted river: part II. In E. Hemingway, The short stories of Ernest Hemingway. New York: Charles Scribner's Sons. (1955).

Mouré, E. Domestic fuel. Toronto: House of Anansi Press. (1985).

Trinh, M. T. When the moon waxes red: Representation, gender and cultural politics. New York: Routledge. (1991).

Walkerdine, V. Schoolgirl fictions. London: Verso. (1990).

Zanuck, R. D., Brown, D. (Producers), Ritchie, M. (Director), \& Benchley, P. (Writer). The island [Film]. MCA Distributors. (1981). 